\title{
Group Identity and Ingroup Bias: The Social Identity Approach
}

\author{
Maykel Verkuyten \\ Ercomer, Utrecht University, Utrecht, The Netherlands
}

\section{Keywords \\ Group identity · Ingroup bias · Social identity approach}

\begin{abstract}
This article discusses the social identity approach (social identity theory and self-categorization theory) for understanding children's ingroup biases in attitudes and behaviors. It is argued that developmental research on ingroup bias will be enhanced by more fully considering the implications of this approach. These implications include (a) the conceptualization of group identity, (b) the importance of social reality and children's epistemic motivation, (c) the role of processes of normative influence and social projection, and (d) the relevance of moral considerations. These four implications have not been fully considered in the developmental literature but indicate that the social identity approach offers the possibility for theoretically integrating and empirically examining various processes involved in children's ingroup biases.

(c) 2021 The Author(s) Published by S. Karger AG, Basel
\end{abstract}

(C) 2021 The Author(s)

Published by S. Karger AG, Basel

This is an Open Access article licensed under the Creative Commons Attribution-NonCommercial-4.0 International License (CC BY-NC) (http://www.karger.com/Services/OpenAccessLicense), applicable to the online version of the article only. Usage and distribution for commercial purposes requires written permission.
I watched what had been marvelous, cooperative, wonderful children, turn into nasty, vicious, discriminating, little thirdgraders in a space of fifteen minutes. I think I learned more from the superior children - from the children who were considered to be superior - than I did from the children who were considered inferior, because their personalities changed even more than the others did. Whether they are this, whether this is what they would like to be inside but society inhibits them, I don't know, but for one day we removed their inhibitions, and they were ghastly. Jane Elliot

In 1968, one day after the assassination of Martin Luther King Jr., Jane Elliott, a primary schoolteacher in Iowa, decided to make the children in her elementary school class experience discrimination and racism. She carried out a famous two-day classroom intervention, which was recorded in the award-winning documentary The Eye of the Storm (Peters, 1970). All of her students were white and, to teach them something about race and racism, the documentary shows Elliott asking the class whether there is something that makes the children different from each other. One of the children suggested the color of their eyes. Elliott adopted the idea and divided the class into children with blue eyes and children with brown eyes. To make the distinction clearly visible, she had the two groups wear collars of a different color. This process of classification

Correspondence to:

Maykel Verkuyten, m.verkuyten@uu.nl 
changed the situation from one in which there were individual pupils to a situation of two "racial" groups. The quote above describes what according to Elliott subsequently happened and why this might be.

Elliott's exercise is not a scientific study, raises various ethical issues, and academic research does not support her interpretations (e.g., "change of personality"). However, throughout the paper I will use Elliott's exercise and the documentary only for illustrative purposes as it is very helpful for explaining, in a concrete way, what is involved in group identities and how these affect relations between children. Theoretically, I will discuss the social identity approach which includes social identity theory and selfcategorization theory (Reicher et al., 2010). The original minimal group experiments in which participants are randomly placed in ad hoc groups and that formed the basis of this approach were first conducted with Dutch early adolescents (Rabbie \& Horowitz, 1969) and then British school children (Tajfel et al., 1971). The social identity approach, however, is not a developmental theory but a social psychological perspective. Yet, developmental social psychologists have provided developmental specifications to the social identity approach (e.g., Killen \& Rutland, 2011; Nesdale, 2017; Verkuyten, 2016), and this approach has been increasingly used to account for children's ethnic, racial, national, gender, novel and other group biases in different settings and contexts (e.g., Abrams et al., 2008; Dunham et al., 2011; Spielman, 2000). Much of this research has been conducted among majority group children (up to around 12 years) and in the context of the United States and Western Europe, and this limitation is reflected in the research that will be discussed.

I will first give a short overview of the main points of the social identity approach which is followed by a discussion of three interrelated aspects of the conceptualization of group identities and their public nature. Then I will elaborate on what is involved in intergroup behavior or children's thinking, feeling and acting in terms of their group membership and in relation to other groups. This is followed by a discussion of ingroup bias and the striving for a positive group self in relation to reality constraints, processes of normative influence and social projection, and moral considerations. The overall aim is to demonstrate the broad usefulness of the social identity approach for understanding children's ingroup biases, by discussing the nature of group identities and by focusing not only on the importance of establishing a positive group self but also on other processes, and epistemic motivation in particular (Piaget, 1929).

\section{The Social Identity Approach}

The social identity approach focuses on explaining attitudes and behavior as the outcome of the interaction between psychological processes with social, cultural and political circumstances. It is emphasized that the way in which psychological processes play out is dependent upon how the social world is structured. There are three features of this approach that are especially relevant for understanding children's ingroup biases and that I will discuss and develop further in the various sections of the paper.

First, the social identity approach focuses on the processes involved in making group distinctions and the ways in which people define themselves and others as members of social groups. Group identity is simultaneously social and individual, public and private. It is considered a key construct for conceptualizing the relationship between the individual and society: identity is "the best device I know for bringing together 'public issues' and 'private troubles"' (Jenkins, 1997, p. 3). Group identity involves public images (social distinctions) that inform private understandings (sense of self). What a racial, ethnic or other group identity means cannot be reduced to a person's own perspective and idiosyncratic beliefs since it involves social reality in the form of shared meanings that are enshrined in, for example, rules, regulations, symbols, collective representations and cultural narratives (Verkuyten, 2018). This means that children have to learn what these public images are and gradually have to develop a sense of self based upon the images of the groups to which they belong.

Second, according to the social identity approach, group identity is what makes group behavior possible because it fundamentally changes and transforms people's psychology and behavior. People think, feel and behave not only as individuals ("I"; e.g., personal self-esteem, personal interests) but also as group members with shared perceptions, understandings and goals ("we"; e.g., collective self-esteem, collective interests). With the act of defining oneself as a group member, the normative group understandings become self-relevant. There is a process of self-stereotyping in which one starts to understand oneself and others in terms of the norms, beliefs and values associated with that particular group identity.

Third, group identities provide a sense of ingroup belonging with the related tendency to seek positive group distinctiveness along valued dimensions of intergroup comparison. Because of their need for a positive group self, people tend to show ingroup bias. They try to en- 
hance their sense of self-esteem by positively differentiating their ingroup from relevant outgroups on those dimensions that matter to their group. However, according to the social identity approach and the related social identity developmental theory (Nesdale, 2017), such a bias is by no means an automatic product of group distinctions. In addition to the strength of group identification and perceived outgroup threat (Nesdale, 2017), ingroup bias depends on social reality, prevailing social norms and moral considerations. Children do not only want to have a positive group self, but also want to develop an adequate understanding of social reality, are influenced by the norms of their group and try to do the morally right thing. Ingroup bias is multiply determined, and multiple explanations for bias in the real world, but also in minimal group experiments, co-exist (Spears \& Otten, 2012). An explanation in terms of striving for a positive group self does not dismiss an explanation in terms of the epistemic desire to form an adequate understanding of social reality, a normative explanation, or a moral explanation (Abrams et al., 2008; Killen et al., 2016). Similar to adults, children's intergroup behavior is likely to be driven by multiple motivations that interact with the tendency to make a positive distinction in favor of one's own group.

\section{Group Identities as Social Realities}

In growing up, children increasingly become aware of the social distinctions that matter in society. They live in a pre-structured social world in which various differences between people are considered relevant, made meaningful in particular ways, and used to label individuals and interpret their behavior. The particular features and their meanings differ between societies, cultures and historical periods but distinctions based on, for example, age, gender, religion, language, race and ethnicity are common in most settings. From the beginning, infants are strongly interested to learn about how the social world is organized and made meaningful: what matters to society matters to them for knowing what the world is like and where they and others fit in and belong. For example, infants use language and accents as social markers and intuitively use native speakers as a particularly good source of culturally relevant information (Kinzler, 2021). Further, children as young as 4 make inferences about unknown groups only when generic information is communicated by a speaker who is considered to know a lot about these groups (Moty \& Rhodes, 2021).

Group Identity and Ingroup Bias: The

Social Identity Approach
Group identities are about socially defined and recognized distinctions and designations. They imply intersubjective understandings that conceptually involve three interrelated components (Verkuyten, 2018): (a) social classification, or the sociostructural component, (b) specific behavioral and normative consequences and expectations bounded to the category, or the cultural component, and (c) judgements of an ontological nature, or the psychological component. Together, these three are the necessary and closely linked public aspects of what defines a group identity. The distinction between the three aspects is a conceptual, analytic one that allows us to ask specific questions and to examine in detail how the social world is organized and the ways in which people come to understand their social world. However, in everyday life the three aspects are closely interrelated and intermingled, and the importance of making an analytic distinction between the three is not always easy to see. The Jane Elliott example is useful here because it involves the formation of new group identities, based on eye color.

\section{Social Classification}

First of all, there is the social classification of people into categories or groups. Children are predisposed to see the world in categories and attuned to cues that mark social difference. The social world is organized in many different ways, and these organizations are learned from an early age on and used to make distinctions between individuals. Group identity is a public reality - an assignment that divides people on the basis of particular criteria that can be used in different combinations including forms of intersectionality. Hence, people can be included or excluded on many different grounds and children learn that individuals can be categorized in different ways based on cues that are socially meaningful in a particular context.

Categorizing people, and hence differentiating between them, happens everywhere in society and for a variety of reasons. It occurs in everyday life and is a prerequisite for group functioning and the organization of society because people differ in their positions, capabilities, life circumstances, needs and desires. Making distinctions between groups of people is often functional and relevant, but also forms the basis for ingroup bias from a young age onwards (Bigler \& Liben, 2007; Liberman et al., 2017). However, this does not have to imply outgroup negativity: making distinctions does not necessarily imply creating oppositions (Nesdale, 2017). Already infants show a preference for ingroup members because these

Human Development 2021;65:311-324 313 
members are considered similar to themselves, are often more familiar and can provide relevant group information, whereas outgroup dislike tends to develop around the age of 6 (Buttelmann \& Böhm, 2014; Cameron et al., 2001), although it can develop earlier in deeply divided societies (Nasie et al., 2016).

Elliott used a visible classification that changed the classroom setting to a situation of two "racial" groups. She construed the relevant categories in a specific way, and she could have done so in another way. The tensions and conflicts that did arise in the classroom are not the inevitable consequences of creating a categorial distinction. For example, she could have used another, less visible, feature to make a distinction between groups of children (e.g., hobbies) and lower perceptual salience leads to less ingroup bias among children (e.g., Bigler et al., 1997). Or, she could have made a tripartite distinction between blue, brown and green eyes, or combine two categorization dimensions as a form of intersectionality (e.g., eye color and gender). The children's understanding of themselves and each other might have been quite different and the intergroup processes are likely to be different in a "blue, brown, green" world compared to a binary "blue, brown" world. Similar to Elliott, the great majority of research on children's ingroup biases uses a binary framework and, in doing so, tends to ignore more complex situations. Some experimental research among children that does use a third group has found only signs of ingroup bias within a competitive setting (e.g., Hartstone \& Augoustinos, 1995; Spielman, 2000). Additionally, experimental work combining two categorization dimensions (e.g., gender and ethnicity) has found lower ingroup bias and more complex patterns of intergroup differentiation with, for example, intersecting categories (ingroup member on one dimension - e.g., gender - and an outgroup on the other dimension - e.g., ethnicity) being evaluated more positively than those who differ on both categorization dimensions (e.g., Brewer et al., 1987; Vanbeselaere, 1987). Following the social identity approach, one explanation for these findings is that a third group as well as the combination of categorization dimensions makes a binary distinction less salient and adequate which can influence responses to outgroup members.

\section{Behavioral and Normative Meanings}

A meaningful group identity does not only involve social classification, but also stereotypical expectations and behavioral consequences that provide shared content and meaning. Group identities are associated with particular (implicit and explicit) scripts, or socially recognized cultural meanings and norms of behavior that provide guidelines for how to think, feel and act in the social world. Even infants expect group members to behave in similar ways (Powell \& Spelke, 2013), and children (4-years and older) prefer to learn from informants in consensus with one another (Chen et al., 2013) and use information about how a group is for making inference about how individual group members will and should be (Roberts et al., 2021).

Because eye color does not ordinarily have any categorical significance, this distinction can be used to make it meaningful in all sorts of ways. In her classroom, Elliott proceeded to define and treat the one group as if they were inferior people (and the other, superior) and the next day she subjected the other group to the same treatment. She did this by defining clear behavioral consequences. For example, the "inferior" children had to sit at the worst places in the back of the class, had to go last in line, were not allowed to use paper cups to drink from the water fountain, got no extra minutes at recess and were not allowed to go for seconds in the cafeteria. Further, she defined the two groups as deserving their inferior or superior treatment because of their alleged intrinsic differences ("The brown-eyed people are the better people in this room. They are cleaner and they are smarter, more civilized"). Thus, the categorization was made normative, and having blue or brown eyes was no longer an insignificant feature, but became consequential and meaningful ("We are intelligent and hence we look down upon them as stupid").

However, Elliott could have made the same bluebrown distinction meaningful in another way with other behavioral implications. Rather than "superior" and "inferior," she could have defined the distinction in terms of "being different" and "being complementary." If she wanted to teach the children something about cooperation and the positive aspects of diversity, such a definition would be appropriate ("We are different and therefore can learn from them"). Although the same categorical distinction would be used (eye color), the consequences for the relationships within the class would be dramatically different and probably in line with the positive implications of multiculturalism for ingroup bias (Verkuyten \& Thijs, 2013). Yet, in the case of "superior" and "inferior," the situation can still develop in various directions depending on the particular meanings involved. "Superior" can also mean that you are expected to help the "inferior" children as much as possible and to be concerned 
about their ups and downs ("We are charitable and therefore help them"). Ingroup meanings can be prosocial and Elliott could have introduced such an understanding rather than define the group distinction in terms of unequal rights. Again, the consequences would have been different from those seen in the documentary: prosocial norms have been found to instigate more positive outgroup attitudes (e.g., Nesdale \& Lawson, 2011) and to stimulate children's helping behavior (e.g., Sierksma et al., 2014). The "superior" children can still feel valued and positive about themselves, but in this case because they belong to a group that help those in need of support. And the "inferior" children will feel accepted and cared for rather than excluded and rejected.

Experimental research tends to examine children's ingroup bias using ad hoc minimal groups in which the division into two categories is made self-relevant and becomes all-important, the only available ground for making distinctions in favor of one's ingroup. However, the social identity approach argues that attention to the contents of identity is needed for understanding how people in everyday life will respond toward others. Categorical distinctions trigger processes of category differentiation but the beliefs, norms and values associated with a particular identity determine the direction and nature of people's reactions.

\section{Ontological Nature}

Labels for group identities are powerful not only because of the related behavioral expectations and consequences, but also because of the way in which the members of these categories are thought to be like as human beings. The ontological component implies that not all social classifications have to function as group identities in everyday life. For instance, in schools, teachers make use of all sorts of group distinctions for various educational purposes (e.g., children working on different tasks) but these distinctions do not necessarily indicate or develop into social identities that are considered to say something about the nature of groups of children. Social distinctions with specific behavioral consequences sometimes lack the third ontological component since in everyday life these distinctions do not function for defining and indicating what a person is like.

With group identities, knowing to which category someone belongs leads to a judgement about the kind of person they are. Group identities are expressed in the language of nouns that "cut slices" through our social envi-

Group Identity and Ingroup Bias: The

Social Identity Approach ronment (Allport, 1954; Rosenberg, 1979). Someone is a Turk, a Mexican or a Basque. In using such words, no quantifiable qualities are defined, as with adjectives. Descriptions of oneself or others as being religious, intelligent, shy or athletic do not necessarily indicate group identities because they can refer to personal beliefs and personal characteristics. But these same terms might also be used to indicate group identities when referring to membership of a religious group or the category of intellectuals, introverts or athletes. For the social identity approach, the critical issue is whether these terms are used to define people as part of a social group and therefore subject to the related behavioral expectations and beliefs about the nature of the people involved.

Nouns reflect separate social types, with typical characteristics and boundaries that suggest a more than superficial difference. Stating that one is Turkish or Jewish (adjectives) or that one is a Turk or a Jew (nouns) indicates a different degree of essentialist quality (Carnaghi et al., 2008; Gelman \& Heyman, 1999). Already, preschoolers tend to use linguistic labels for kind-based reasoning and develop essentialist conceptions of people related to gender, and depending on the cultural context of race and ethnicity (e.g., Diesendruck et al., 2013; Waxman, 2010). They assume that people who are marked by the same label share an important category membership and are similar to each other. With nouns, one group of people is deemed to be like this, the other, like that. With that, they become real identities with real social and psychological consequences. The labelling and functional usage of novel groups has been found to contribute to the formation of ingroup bias among young children (Bigler et al., 1997; Billig \& Tajfel, 1973).

Elliott turned the distinction into real group identities by starting to use the nouns "blue-eye" and "brown-eye," and in class and on the playground the children themselves started to use these labels for describing and treating others. The labels became informative about the nature of the two groups of children. For example, when the class went to lunch, one "superior" child suggested that Elliott should inform the canteen staff about the rule that the "inferior" children may not be given extra portions and another child suggested that the teacher should keep her pointer on hand in case the "inferior" children were getting out of hand. And during class, the answers given by the "superior" children were interpreted in terms of intelligence and the ability to learn quickly, while the behavior of the "inferior" children was attributed to clumsiness and stupidity: when a blue-eyed student got an arithmetic problem wrong, a brown-eyed pupil said "Well, 
what do you expect from him, Mrs. Elliott, he's a bluey!" Another example that shows that the categories had become real group identities that pupils used to define and understand themselves and others even in the absence of the teacher occurred after recess on the day when the brown-eyed children were considered inferior. One child was withdrawn and agitated because he had gotten into a fight and Elliott asked what had happened:

$\begin{array}{ll}\text { Ms. Elliott: } & \text { What happened, John? } \\ \text { John: } & \text { He called me names. } \\ \text { Ms. Elliott: } & \text { What did he call you? } \\ \text { John: } & \text { Brown-eye. } \\ \text { Pupils: } & \text { They always call us that. "Hey brown-eye, come } \\ & \text { here, brown-eye." } \\ \text { Ms. Elliott: } & \text { What's wrong with being called a brown-eye? } \\ \text { John: } & \text { It means we're stupid and all that. }\end{array}$

\section{Intergroup Behavior}

In this excerpt several pupils use the term "they" and in the last line John refers to "we." Elliott had changed the classroom setting of individual pupils into an intergroup situation with two meaningful "racial" groups. The children started to think, feel and act in terms of "us and them" ("I feel that Ms. Elliott has taken our best friends away from us"). In the opening quote, Elliott talks about a change in personality within the space of $15 \mathrm{~min}$, but from the social identity approach there is a (temporary and situational) change from personal self-understanding ("I") to collective self-understanding ("we").

The children started to label themselves in terms of the category to which they belong ("brown-eye") and distinguished themselves from the category to which they did not belong ("blue-eye"). Research has demonstrated that the process of self-categorization and the ability to talk and think in terms of "us and them" develops early in life. Whereas emotional identification with ingroup members seems to start to develop around 6 years of age, the ability to socially categorize oneself and others develops earlier (Ruble et al., 2004; Sani \& Bennett, 2004). Children quickly learn to which category they belong, and this is a sufficient precondition for ingroup bias (Bennett et al., 1998; Dunham, 2018).

Furthermore, children will start to think, feel and behave in agreement with the way in which the categories are socially meaningful. In Elliott's classroom, the one group started to feel superior and the other group inferior, and the children started to act in terms of how the groups were understood. When you are one of the better people and better means having more rights and privi- leges, then it makes good sense to behave in such a way. In other words, one can argue that within the logic of the situation as defined, the children behaved rationally, reality oriented. However, the children also started to use the labels in name calling, and became arrogant, bossy and otherwise unpleasant to their "inferior" classmates for feeling positive about themselves. This suggests that not only the way in which group identities are made real is important, but also that self-favoring considerations mattered. Furthermore, the name calling and unpleasant behavior was considered mean and wrong by some children ("what he did was mean") which indicates that moral considerations were also relevant.

\section{Social Reality and Ingroup Bias}

One of the central contributions of the social identity approach is that it tries to establish a link between group identities and social reality. Social categories and group understandings are taken to reflect the intersubjective and normative nature of the world people find themselves in. Group stereotypes, for example, are not considered misperceptions but rather conceptualized and empirically found to be sensitive to the intergroup realities in the social world (Oakes et al., 1994). People are organized and understood in terms of meaningful social categories because this is how they are organized and considered in the real world. The children in Elliott's classroom found themselves in a context where pupils are organized by "race" and where thinking in terms of the group differences between "browneyes" and "blue-eyes" fits the social context.

The social identity approach conceptualizes ingroup bias as the interactive result of human motivations and social realities. Children have a strong desire to acquire knowledge and are curious about the meaningful aspects that constitute the world they try to make sense of (Piaget, 1929). An adequate understanding of social reality, including social groups (Hirschfeld, 1996), is a crucial aspect of the process of growing up, and defining the nature of groups as being factual has been found to play a role in early adolescents' discussions about outgroup friendships (Verkuyten \& Steenhuis, 2005). This also means, for example, that knowledgeable authorities such as parents and teachers exert an important influence on the child's understanding and beliefs about social groups.

In Elliott's classroom, she was the authority but her definition of the two group identities was not simply accepted by the children. At first, some children were hesitant and resistant towards her statement that brown-eyed 
people are better than blue-eyed people. The children questioned the notion that the ontological nature of these two groups of children differs. They readily understood that one can make such a distinction and let it have specific social consequences for functional reasons, but not that you can use it to tell something about the types of children involved ("we are like this, and they are like that"). In other words, for some children the ontological component was missing and therefore they did not consider eye color a real social identity. Elliot, however, tried to present her definition as reality-based and accurate, for example, by referring to the eye color of George Washington, by presenting evidence from everyday life, and by stating that melanin was linked to the higher intelligence and learning ability of brown-eyed people ("Brown-eyed people have more of that chemical in their eyes, so browneyed people are better than those with blue eyes"). In doing so, she explicitly stressed several times that it is a fact that brown-eyed people are better than blue-eyed people. This provided the social identity the required "reality depth" so that it became more than a game or a distinction made for educational purposes.

The social identity approach argues that people strive to have a positive sense of their group self and therefore are motivated to evaluate their own group positively: establishing favorable distinctiveness of one's own group vis-àvis other groups (ingroup bias) contributes to a positive self-identity. Research among children has shown that such a bias does indeed positively and causally affect selffeelings (e.g., Verkuyten, 2007). In Elliott's classroom, the "superior" children felt superior and positive about themselves ("I felt that I was better than them, happy"), which was shown in their emotional and facial expressions and the fact that their grades on simple tests were better, and they completed mathematical and reading tasks that had seemed outside their ability before (Ambady et al., 2001).

However, social reality can constrain children's preference for a positive group identity. This is illustrated in the fact that children are well aware of social status differences and that low-status group children are less likely to show ingroup bias on status-related dimensions (Baron, 2015). Furthermore, perceived competence rests on realities of power, status and resources, making ingroup bias on this dimension less malleable than on the dimension of warmth/friendliness (Yzerbyt, 2018). Research has found ingroup bias among infants and young children (e.g., Dunham et al., 2011; Hetherington et al., 2014) but there are also reality constraints that children take into account, such as group differences in wealth, opportunities and performances. In one study, preschool and

Group Identity and Ingroup Bias: The

Social Identity Approach elementary school-age children received bogus scores for an egg-and-spoon race that ostensibly placed them in a fast or a slow team (Yee \& Brown, 1992). The children were also told that members of the fast and slow groups were selected for membership in a particular group on the basis of their performance in the race. Both groups were found to show ingroup bias. However, there was a difference in performance ratings. The ingroup team was rated as faster than the other team by children placed on the fast team, whereas children on the slow team rated their ingroup as slower than the other team. Hence, these performance ratings reflected reality rather than positive group identity concerns that, probably, guided the affective ratings. However, in making self-evaluations and intergroup evaluations 5- and 6-year-olds disregarded factual information more easily than 9- and 10-year-olds (Ruble et al., 1976; Yee \& Brown, 1992).

Reality and children's desire for adequate knowledge can constrain their tendency to make favorable ingroup comparisons on specific dimensions of comparison. Another example is an experimental study among three age groups (6-, 8- and 10-year-olds) that examined trait attribution effects of reality constraints on eye color differences and national group differences (Verkuyten \& De Wolf, 2007). For all three age groups, it was found that children take information about social reality into account when giving intergroup ratings, and when children were not fully convinced about the reality claims that were made in the experiment context thus leaving more room for interpretation, the youngest children were found to show the clearest pattern of ingroup bias. These findings indicate that the striving for a positive group identity is constrained by social reality, as is proposed by the social identity approach. The tendency to feel good about oneself by making a positive distinction in favor of one's own group is bounded by the desire to develop an adequate understanding of the social world one finds oneself in. Thus, in addition to the striving for a positive group self, the social identity approach emphasizes the importance of group level social reality and people's epistemic motivation for understanding ingroup bias. This latter motivation is also considered important for processes of normative influence.

\section{Normative Influence and Social Projection}

Although the children in Elliott's classroom appeared to display ingroup bias in the absence of the teacher (e.g., at the playground), the bias might also be about meeting 
teacher's expectations and Elliott's related praise for work done in class. Children try to make sense of group differences and follow normative expectations and social rules from authorities and those that they develop in interaction with each other. Already, preschoolers recognize, create, follow and enforce social norms (Schmidt \& Rakoczy, 2018), and peer groups develop shared understandings of the social world as well as group norms.

An increasing number of studies argue and demonstrate that social norms matter for children's intergroup relations. For example, the social identity development model (Nesdale, 2017) and the developmental subjective ingroup dynamics model (Abrams et al., 2008) state that children's ingroup biases depend on the norms of their ingroup. Empirically, children's attitudes toward ethnic, racial and other groups have been found to be affected by experimentally induced (e.g., Nesdale \& Dalton, 2011) as well as perceived peer group norms (e.g., Brenick \& Romano, 2016). For instance, children use their understanding of group loyalty norms as a basis for evaluating peers (Abrams et al., 2008; Rutland et al., 2015).

Normative influence is often conceptualized as complying with the group, based on children's motivation to gain or maintain social approval and avoid disapproval. Normative influence is considered externally motivated in its focus on social acceptance and belonging which makes children respond publicly without ingroup bias and outgroup negativity (Rutland, 2004). However, there is also informational influence which is considered "true" influence because it leads to the internalized acceptance of messages. This relates, for example, to the research on the formative role that parents and teachers play in the development of children's outgroup attitudes (e.g., Degner \& Dalege, 2013; Geerlings et al., 2019).

In the social identity approach, group influence is less about normative compliance but rather reflects an internal process, akin to informational influence (Turner, 1991). Group members tend to trust their ingroup, which as a refence group is considered to provide valid and relevant information about the world. Children who selfcategorize as a group member rely on ingroup members for their epistemic goals and social reality testing, and not only for gaining social approval. Infants and children prefer to learn from ingroup, compared to outgroup, members who provide relevant cultural information (Begus et al., 2016) and are considered more trustworthy (Chen et al., 2013). Furthermore, with the act of defining oneself as a group member, the shared group understandings become self-relevant. You start to understand yourself and others in terms of the norms, beliefs and values associated with that particular group identity. A process of self-stereotyping occurs whereby the child comes to think about $\mathrm{him} /$ herself in terms of the attributes, characteristics and behavioral expectations that are commonly associated with what it means to be, for example, a "blue-eyed" or "brown-eyed" person.

Processes of self-stereotyping imply that the self extends beyond the individual person to an inclusive social unit ("I am like my group"). With age, children develop an increasing social understanding of group differences and what characterizes various groups, including their ingroup. This is important because the process of self-stereotyping requires such an understanding that makes the assimilation of the self to typical ingroup attributes and characteristics possible. This understanding depends, in turn, on children's cognitive capabilities, their social experiences and the information provided by the social surrounding. In a Piagetian perspective, young children tend to assume that other people see, hear and feel the same as the child does. From middle childhood on, children become less self-centered and increasingly interested in group differences, develop perspective-taking abilities and have more experiences with groups in various situations. As a result, they become more sensitive to group norms and develop abstract understandings of intergroup differences (Karcher \& Fischer, 2004). Research on gender categories, for example, has shown that already in middle childhood, children are able to gender self-stereotype (Sani \& Bennett, 2004). Further, experimental research among preadolescents (10-12 years) has found evidence for self-stereotyping differences depending on the particular cultural identity that is salient (Verkuyten \& Pouliasi, 2002).

In Elliott's classroom, the nature of the two groups was made explicit, which made it relatively easy for the children to think about themselves in the related group terms. However, such a process of self-stereotyping is more difficult when children are faced with groups that lack clarity in their identity content (Van Veelen et al., 2016). For example, moving to an unfamiliar setting or to a context with high cultural diversity and rapid cultural changes often implies that groups are diverse and also ambiguously defined. In such contexts there is no clear group information readily and consensually available to assimilate the self to, which means that self-stereotyping is more difficult.

However, because children expect others of their ingroup to be similar to themselves, a process of social projection is likely in these situations. With social projection, personal attributes are projected onto the ingroup ("the 
group is like me"), and it is assumed that others have similar views and beliefs as the self (Robbins \& Krueger, 2005). From a developmental perspective, this process is more likely among younger (4-6 years old) children who tend to differentiate less between themselves and others and have less advanced perspective-taking abilities (Abrams, 2011). However, social projection is not simply a matter of children's focus on themselves or limited cognitive abilities but occurs at all ages and especially when the information about one's ingroup and its members is rather unclear or hard to believe (Van Veelen et al., 2016). For example, older children (10 years onwards) do not want to come across as prejudiced. They tend to avoid acknowledging race even when it is a relevant category (Apfelbaum et al., 2008) and inhibit the expression of ingroup bias (Olson \& Dunham, 2010). This makes it rather difficult to know what peers really think about particular outgroups. As a result, social projection is more likely whereby children assume that ingroup peers have similar outgroup attitudes as themselves.

In a study on attitudes toward various racial groups (White, Black, Chinese), it was found that children's (811 years old) own attitudes were generally unrelated to the actual attitudes of their friends, but strongly associated with the expected friends' attitudes (Aboud \& Doyle, 1996). Thus, children seemed to assume that their friends share their racial attitudes without this being the case. In another survey study, it was examined whether children (9-12 years old) have the tendency to project their own ethnic ingroup favoring attitude on their classroom peers (Thijs \& Verkuyten, 2016). It was found that children's perception of the attitudes of their classmates was partly accurate but also the result of children's own unique attitudes (not shared with their classmates). This tendency of social projection was found among ethnic minority and majority students alike and across age groups. However, the tendency was stronger for children who had a stronger sense of classroom belonging.

In a further study, a longitudinal design was used to demonstrate that children's own unique ethnic attitudes predict their perception of the attitudes of their classmates half a year later (Thijs \& Zee, 2019). This social projection effect was found to be equally strong for 7 - to 9-year-olds and for 10- to 12-year-olds, and among ethnic majority and minority children. Additionally, there was also, although a smaller, social influence effect in that children's perception of the classroom attitudes predicted their own attitude over time. Interestingly, this study found no evidence for social projection in relation to attitudes toward the ethnic majority group. Rather, chil-

Group Identity and Ingroup Bias: The

Social Identity Approach dren were quite accurate in their perception of what their classmates think about majority group children. This suggests that classmates are less likely to refrain from expressing their attitudes toward the secure high-status group and, therefore, that there is less uncertainty about the classroom belief about this group and thus a lower need for social projection (Van Veelen et al., 2016).

The findings of these studies indicate that children are concerned with what their ingroup members think, especially when they have a relatively strong sense of group belonging. However, this does not imply a one-way process of social influence but might involve a process of social projection to ingroups in situations in which children do not fully know, misperceive or misunderstand the views of their ingroup members. This is more likely in some situations than others. For example, and similar to Elliott's exercise, in deeply divided societies, such as Israel and Northern Ireland, or societies with strong ethnic group boundaries, such as Malaysia and Mauritius, children learn from very early on about the relevant group distinctions, making self-stereotyping more likely and processes of social projection less likely (Connolly et al., 2009; Nasie et al., 2016; Ng Tseung Wong \& Verkuyten, 2015).

In contrast, social projection seems more likely in societies and settings in which there are relatively open and overlapping group boundaries and various intersecting identities exist. However, in these situations peer groups can also develop group norms. Those who identify together do not automatically know each other's views or immediately agree with each other. However, group identity is an important basis for mutual influence and developing ingroup consensus (Turner, 1991). The social identity approach argues that there is a process of consensualization in which ingroup members expect and strive to agree. For example, when people think about themselves as belonging to the same ethnic or racial category, there is an expectation of agreement and a motivation to reach consensus on the meanings and implications of the ethnic or racial identity (Haslam et al., 1999). When learning new information, young children look to ingroup, rather than outgroup, members (Begus et al., 2016), and they seek and endorse consensual information from members of their own group, rather than a different group (Chen et al., 2013). A common identity means that one is similar to others in one way or another and belong together, and this leads group members to seek agreement and try to create normative consensus. This means that it is important to examine the ways in which children collectively and interactively develop group understandings and cre- 
ate and enforce social norms (e.g., Connolly, 2001; Van Ausdale \& Feagan, 2002). According to the social identity approach, ingroup bias is a shared product of social processes of influence and communication.

\section{Moral Considerations}

Children want to feel good about their group membership, and they can do so by making a positive distinction in favor of their own group. However, this is not unrestricted because there is also the need to develop an adequate understanding of social reality and there are relevant group norms. Furthermore, there are moral considerations that can constrain the tendency to favor one's ingroup (Killen et al., 2016).

In the documentary about Elliott's exercise, there is talk about being mean and about fairness. For example, the name calling and teasing that occurred are called by some children as being mean and wrong. At the end of the documentary, Elliott talks about the unfairness of discrimination: "We are treating people a certain way because they are different from the rest of us. Is that fair?," to which the children reply "no," after which she continues with "nothing fair about it. We did not say this was going to be a fair day, did we ('No'), and it isn't. It is a horrid day."

According to sociocognitive domain theory (Turiel, 2002), children's social reasoning can reflect psychological, conventional and moral considerations. From early childhood on, children apply these forms of reasoning to understand social behavior. Moral considerations relate predominantly to issues of well-being and fairness and are considered objective, obligatory, inalterable and relatively independent from authority and peer influences (Skitka et al., 2021). Moral criteria are general and apply to ingroup and outgroup behavior, and moral information curbs children's ingroup bias because they feel internally obligated to act on it. Moral principles like fairness and equality are often privileged in children's reasoning and can trump what group stereotypes and group norms prescribe. Children (4 years onwards), for example, tend to give priority to fairness over stereotypic gender expectations in gender relations (Killen et al., 2001), use moral reasoning to evaluate gender and ethnic exclusion (Møller $\&$ Tenenbaum, 2011), demonstrate less ingroup bias in morality-based judgments compared to conventionbased judgments (e.g., Abrams et al., 2008), and sometimes hardly show any ingroup bias in rejections of unfair allocations (Gonzalez et al., 2020, but see Fehr et al., 2008) and in explaining a perpetrator's victimization behavior (Verkuyten, 2003). Further, in settings marred by religious conflict (India), older children judge it wrong to harm religious others (Srinivasan et al., 2019), and children prioritize cooperative helping norms when these conflict with group identity concerns (Gonzalez-Gadea et al., 2020).

Furthermore, research demonstrates that children as young as 7 years understand the difference between having external and internal reasons for outgroup attitudes (Hughes et al., 2016; Jargon \& Thijs, 2020). External reasons entail the desire to conform to social norms and avoid social disapproval, while internal reasons stem from moral beliefs about equality, harm and fairness. Internal reasons tend to be more strongly and consistently associated with outgroup acceptance than external reasons (Hughes et al., 2016). For example, research among older children (9-12 years) in elementary schools has found that egalitarian and equality messages can stimulate self-endorsed reasons for accepting outgroups, whereas explicit prosocial norms lead to concerns about social sanctions and compliance (Jargon \& Thijs, 2020). Furthermore, trait-like empathetic (Miklikowska, 2012) as well as situationally induced empathic understanding (Sierksma et al., 2015) can overcome children's ingroup biases. Empathic concern implies that one cares for the well-being of others and experiences parallel emotions, which is related to more positive outgroup attitudes (Nesdale et al., 2005; Van Bommel et al., 2021). In one study, children were found to empathize with asylum seekers who had to flee their country and leave their friends behind, arguing that "a refugee can really use my friendship," and "it is very sad and so, and then you want to be friends with them" (Verkuyten \& Steenhuis, 2005). Children can empathize with others and are intrinsically motivated to help others from a very young age onwards (e.g., Fehr et al., 2008; Schmidt \& Sommerville, 2011; Warneken \& Tomasello, 2006).

Some research using the minimal group paradigm has observed that children's choices tend to represent a balancing or coordination between the goals of ingroup bias and considerations of fairness (Branthwaite et al., 1979; Tajfel, 1970; see also Turiel \& Gingo, 2017), that strategies of fairness and equality are more common in children's punishment behavior (McAuliffe \& Dunham, 2017) and in negative outcomes and allocating sanctions between ingroups and outgroups (Rutland et al., 2007), and that 4- and 5-year-olds' ingroup preference is significantly attenuated in the presence of an antisocial ingroup member (Hetherington et al., 2014). These findings indicate that 
developing a positive group self is not the only thing that matters for how children relate to other groups, not even in minimal group settings.

The importance of moral concerns is compatible with the social identity approach because the content of group identity, for example, can emphasize moral values ("we are fair-minded, charitable, honest”; Ellemers, 2017) and because the findings mentioned might be interpreted in terms of the level of self-categorization. Being asked to administer negative outcomes is unusual and rather socially inappropriate and therefore might lead in a minimal group setting to a recategorization into "us" (the two groups) versus "them" (i.e., the experimenters) which reduces the categorical difference between the two groups and the related ingroup bias (Gardham \& Brown, 2001).

The social identity approach argues that people can think about themselves at different levels of abstraction, such as an ethnic group member, a national and a human being. All these levels have their own specific identity contents, and the moral value of egalitarianism and fairness is prevalent within superordinate identities like shared nationality and common humanity. Whereas children can favor their ethnic or racial ingroup, there is, at the superordinate level of society and humanity, the moral principle to treat all individuals and groups equally, fairly and without harm. These principles go beyond the specific intergroup situation by foregrounding a superordinate identity with the related moral values that proscribe ingroup bias and encourage intergroup fairness (Iacoviello \& Spears, 2018). For example, children have been found to explain that it is unfair and discriminatory to not want to be friends with an outgroup peer since "we are all just humans" and "they are normal children or people, just like us" (Verkuyten \& Steenhuis, 2005).

\section{Conclusions}

According to the social identity approach, group identity underlies ingroup bias. It is because children are able to conceive of themselves and others as group members that they are able to differentiate their ingroup from outgroups. Children want to understand their social world and define themselves in terms of the social realities that are meaningful in particular settings, cultures or historical periods. Their own group provides them with relevant information about how to understand the social world and their own place in it, and gives them a sense of belonging. Children have a strong epistemic motivation, want to belong, and are concerned with maintaining or developing

Group Identity and Ingroup Bias: The

Social Identity Approach a positive sense of self. Furthermore, striving for a positive group self and the resulting tendency to favor one's ingroup does not tell us much about how this is achieved. There are many ways in which one's group can stand out positively, such as by being competitive or, rather, by being cooperative and supportive. The direction for how to act is provided by the way in which the particular group distinction is made meaningful. When, in a particular situation, children see themselves as members of a group, they will think, feel and act in terms of the norms, values and beliefs that are considered to characterize the group, and these can also be prosocial and moral.

There are various possible reasons for ingroup bias and the particular forms that it takes. This makes it important to try to examine the development of the different processes and how these can simultaneously affect children's attitudes and behavior. Obviously, the striving for a positive group self is important but ingroup bias is likely to be multiply determined and also dependent on epistemic motivations, social influences and moral considerations. The "superior" children in Elliott's exercise did not only feel positive and happy about themselves, but they also started to think and act in terms of the logic of the situation as defined and raised moral concerns about the negative intergroup behavior that occurred. The social identity approach does not only focus on ways to establish a positive identity but provides a framework for thinking about the role of other motivations and considerations that also develop early in life. Much of children's social life involves balancing multiple considerations, and this includes questions about the nature of group distinctions and the implications that these have for oneself and others. Further, developmental research is required in order to fully understand how this balancing process develops and plays out in children's ingroup biases in different sociocultural contexts.

Although much of the research on ingroup biases is conducted among majority group children in Western societies, the social identity approach emphasizes that the way in which psychological processes play out is dependent upon the local and broader societal context. It is important to know that children strive for a positive group identity, but that tells us little about how this is achieved, and which group distinctions are considered relevant, what they mean and how they feature in children's lives. Intergroup biases can take different forms in different local contexts (e.g., schools, neighborhoods), and children's understanding and evaluation of group differences are likely to be different in, for example, strongly racialized and unequal societies (United States, South Africa) than in more multicultural and egalitarian nations (e.g., Singapore, New Zealand). The 
social identity approach has much more to offer than the well-known prediction that children tend to show ingroup bias because of their need for a positive group self. The approach offers a theoretical framework that is broader and richer in focusing on cognitive and motivational processes and how these operate and work out within the local and broader social world in which children grow up.

\section{Statement of Ethics}

No ethical approval was required for the preparation of this paper, as no human or animal subjects were used.

\section{Conflict of Interest Statement}

The author has no conflicts of interest to declare.

\section{Funding Sources}

While working on this paper, the author was supported by a European Research Council Advanced Grant under the European Union's Horizon 2020 research and innovation program (grant No. 740788)

\section{References}

Aboud, F. E., \& Doyle, A. B. (1998). Parental and peer influences on children's racial attitudes. International Journal of Intercultural Relations, 20(3-4), 371-383. https://doi.org/ 10.1016/0147-1767(96)00024-7

Abrams, D. (2011). Wherein lies children's intergroup bias? Egocentrism, social understanding, and social projection. Child Development, 82(5), 1579-1593. https://doi.org/10.1111/ j.1467-8624.2011.01617.x

Abrams, D., Rutland, A., Ferrell, J. M., \& Pelletier, J. (2008). Children's judgments of disloyal and immoral peer behavior: Subjective group dynamics in minimal intergroup contexts. Child Development, 79(2), 444-461. https:// doi.org/10.1111/j.1467-8624.2007.01135.x

Allport, G. W. (1954). The nature of prejudice. Addison-Wesley.

Ambady, N., Shih, M., Kim, A., \& Pittinsky, T. L. (2001). Stereotype susceptibility in children: Effects of identity activation on quantitative performance. Psychological Science, 12(5), 385-390. https://doi.org/10.1111/14679280.00371

Apfelbaum, E. P., Pauker, K., Ambady, N., Sommers, S. R., \& Norton, M. I. (2008). Learning (not) to talk about race: When older children underperform in social categorization. Developmental Psychology, 44(5), 1513-1518. https://doi.org/10.1037/a0012835

Baron, A. S. (2015). Constraints on the development of implicit intergroup attitudes. Child Development Perspectives, 9(1), 50-54. https://doi.org/10.1111/cdep.12105

Begus, K., Gliga, T., \& Southgate, V. (2016). Infants' preferences for native speakers are associated with an expectation of information. Proceedings of the National Academy of Sciences of the United States of America, 113(44), 12397-12402. https://doi.org/10.1073/pnas. 1603261113

Bennett, M., Lyons, E., Sani, F., \& Barrett, M. (1998). Children's subjective identification with the group and in-group favoritism. Developmental Psychology, 34(5), 902-909. https://doi.org/10.1037/0012-1649.34.5.902
Bigler, R. S., Jones, L. C., \& Lobliner, D. B. (1997). Social categorization and the formation of intergroup attitudes in children. Child Development, 68(3), 530-543. https://doi.org/ $10.2307 / 1131676$

Bigler, R. S., \& Liben, L. S. (2007). Developmental intergroup theory: Explaining and reducing children's social stereotyping and prejudice. Current Directions in Psychological Science, 16(3), 162-166. https://doi.org/10.1111/ j.1467-8721.2007.00496.x

Billig, M., \& Tajfel, H. (1973). Social categorization and similarity in intergroup behaviour. European Journal of Social Psychology, 3(1), 37-52. https://doi.org/10.1002/ejsp. 2420030103

Branthwaite, A., Doyle, S., \& Lightbrown, N. (1979). The balance between fairness and discrimination. European Journal of Social Psychology, 9(2), 149-163. https://doi. org/10.1002/ejsp.2420090204

Brenick, A., \& Romano, K. (2016). Perceived peer and parent out-group norms, cultural identity, and adolescents' reasoning about peer intergroup exclusion. Child Development, 87(5), 1392-1408. https://doi.org/10.1111/ cdev. 12594

Brewer, M. B., Ho, H.-K., Lee, J.-Y., \& Miller, N. (1987). Social identity and social distance among Hong Kong schoolchildren. Personality and Social Psychology Bulletin, 13(2), 156$165 . \quad$ https://doi.org/10.1177/ 0146167287132002

Buttelmann, D., \& Böhm, R. (2014). The ontogeny of the motivation that underlies in-group bias. Psychological Science, 25(4), 921-927. https://doi.org/10.1177/0956797613516802

Cameron, J. A., Alvarez, J. M., Ruble, D. N., \& Fuligni, A. (2001). Children's lay theories about ingroups and outgroups: Reconceptualizing research on prejudice. Personality and Social Psychology Review, 5(2), 118-128. https://doi. org/10.1207/S15327957PSPR0502_3
Carnaghi, A., Maass, A., Gresta, S., Bianchi, M., Cadinu, M., \& Arcuri, L. (2008). Nomina sunt omina: On the inductive potential of nouns and adjectives in person perception. Journal of Personality and Social Psychology, 94(5), 839-859. https://doi.org/10.1037/0022-3514. 94.5.839

Chen, E. E., Corriveau, K. H., \& Harris, P. L. (2013). Children trust a consensus composed of outgroup members - But do not retain that trust. Child Development, 84(1), 269-282. https://doi.org/10.1111/j.14678624.2012.01850.x

Connolly, P. (2001). Qualitative methods in the study of children's racial attitudes and identities. Infant and Child Development, 10(4), 219-233. https://doi.org/10.1002/icd.280

Connolly, P., Kelly, B., \& Smith, A. (2009). Ethnic habitus and young children: A case study of Northern Ireland. European Early Childhood Education Research Journal, 17(2), 217-232. https://doi.org/10.1080/13502930902951460

Degner, J., \& Dalege, J. (2013). The apple does not fall far from the tree, or does it? A meta-analysis of parent-child similarity in intergroup attitudes. Psychological Bulletin, 139(6), 1270-1304. https://doi.org/10.1037/ a0031436

Diesendruck, G., Goldfein-Elbaz, R., Rhodes, M., Gelman, S., \& Neumark, N. (2013). Cross-cultural differences in children's beliefs about the objectivity of social categories. Child Development, 84(6), 1906-1917. https://doi.org/ $10.1111 /$ cdev. 12108

Dunham, Y. (2018). Mere membership. Trends in Cognitive Sciences, 22(9), 780-793. https:// doi.org/10.1016/j.tics.2018.06.004

Dunham, Y., Baron, A. S., \& Carey, S. (2011). Consequences of "minimal" group affiliations in children. Child Development, 82(3), $793-$ 811. https://doi.org/10.1111/j.1467-8624.2011. 01577.x

Ellemers, N. (2017). Morality and the regulation of social behavior: Groups as moral anchors. Routledge. 9781315661322 
Fehr, E., Bernhard, H., \& Rockenbach, B. (2008). Egalitarianism in young children. Nature, 454(7208), 1079-1083. https://doi.org/ 10.1038 /nature 07155

Gardham, K., \& Brown, R. (2001). Two forms of intergroup discrimination with positive and negative outcomes: Explaining the positivenegative asymmetry effect. British Journal of Social Psychology, 40(Pt 1), 23-34. https://doi. org/10.1348/014466601164678

Geerlings, J., Thijs, J., \& Verkuyten, M. (2019). Preaching and practicing multicultural education: Predicting students' outgroup attitudes from perceived teacher norms and perceived teacher-classmate relations. Journal of School Psychology, 75, 89-103. https://doi. org/10.1016/j.jsp.2019.07.003

Gelman, S. A., \& Heyman, G. D. (1999). Carroteaters and creature-believers: The effects of lexicalization on children's inferences about social categories. Psychological Science, 10(6), 489-493. https://doi.org/10.1111/14679280.00194

Gonzalez, G., Blake, P. R., Dunham, Y., \& McAuliffe, K. (2020). Ingroup bias does not influence inequity aversion in children. Developmental Psychology, 56(6), 1080-1091. https://doi.org/10.1037/dev0000924

Gonzalez-Gadea, M. L., Santamaría-García, H., Aragón, I., Santamaría-García, J., Herrera, E., Ibáñez, A., \& Sigman, M. (2020). Transgression of cooperative helping norms outweighs children's intergroup bias. Cognitive Development, 54, 100878. https://doi.org/10.1016/j. cogdev.2020.100878

Hartstone, M., \& Augoustinos, M. (1995). The minimal group paradigm: Categorization into two versus three groups. European Journal of Social Psychology, 25(2), 179-193. https://doi.org/10.1002/ejsp.2420250205

Haslam, S. A., Oakes, P. J., Reynolds, K. J., \& Turner, J. C. (1999). Social identity salience and the emergence of stereotype consensus. Personality and Social Psychology Bulletin, 25(7), 809-818. https://doi.org/10.1177/ 0146167299025007004

Hetherington, C., Hendrickson, C., \& Koenig, M. (2014). Reducing an in-group bias in preschool children: The impact of moral behavior. Developmental Science, 17(6), 1042-1049. https://doi.org/10.1111/desc.12192

Hirschfeld, L. A. (1996). Race in the making: Cognition, culture, and the child's construction of human kinds. MIT Press.

Hughes, J. M., Alo, J., Krieger, K., \& O’Leary, L. (2016). Emergence of internal and external motivations to respond without prejudice in White children. Group Processes \& Intergroup Relations, 19(2), 202-216. https://doi. org $/ 10.1177 / 1368430215603457$

Iacoviello, V., \& Spears, R. (2018). "I know you expect me to favor my ingroup": Revisiting Tajfel's original hypothesis of the generic norm explanation of ingroup favoritism. Journal of Experimental Social Psychology, 76, 88-99. https://doi.org/10.1016/j.jesp.2018. 01.002
Jargon, M., \& Thijs, J. (2020). Antiprejudice norm and ethnic attitudes in preadolescents: A matter of stimulating the "right reasons". Group Processes \& Intergroup Relations, 24(3), 468-487. https://doi.org/10.1177/1368430220902535

Jenkins, R. (1997). Rethinking ethnicity: Arguments and explorations. Sage.

Karcher, M. J., \& Fischer, K. W. (2004). A developmental sequence of skills in adolescents' intergroup understanding. Journal of Applied Developmental Psychology, 25(3), 259-282. https://doi.org/10.1016/j.appdev.2004.04.001

Killen, M., Elenbaas, L., \& Rutland, A. (2016). Balancing the fair treatment of others while preserving group identity and autonomy. $\mathrm{Hu}$ man Development, 58(4-5), 253-272. https:// doi.org/10.1159/000444151

Killen, M., Pisacane, K., Lee-Kim, J., \& ArdilaRey, A. (2001). Fairness or stereotypes? Young children's priorities when evaluating group exclusion and inclusion. Developmental Psychology, 37(5), 587-596. https://doi. org/10.1037/0012-1649.37.5.587

Killen, M., \& Rutland, A. (2011). Children and social exclusion: Morality, prejudice and group identity. Wiley-Blackwell. https://doi. org/10.1002/9781444396317

Kinzler, K. D. (2021). Language as a social cue. Annual Review of Psychology, 72(1), 241-264. https://doi.org/10.1146/annurevpsych-010418-103034

Liberman, Z., Woodward, A. L., \& Kinzler, K. D. (2017). The origins of social categorization. Trends in Cognitive Sciences, 21(7), 556-568. https://doi.org/10.1016/j.tics.2017.04.004

McAuliffe, K., \& Dunham, Y. (2017). Fairness overrides group bias in children's secondparty punishment. Journal of Experimental Psychology. General, 146(4), 485-494. https:// doi.org/10.1037/xge0000244

Miklikowska, M. (2012). Psychological underpinnings of democracy: Empathy, authoritarianism, self-esteem, interpersonal trust, normative identity style, and openness to experience as predictors of support for democratic values. Personality and Individual Differences, 53(5), 603-608. https://doi.org/10.1016/j. paid.2012.04.032

Møller, S. J., \& Tenenbaum, H. R. (2011). Danish majority children's reasoning about exclusion based on gender and ethnicity. Child Development, 82(2),520-532.https://doi.org/10.1111/ j.1467-8624.2010.01568.x

Moty, K., \& Rhodes, M. (2021). The unintended consequences of the things we say: What generic statements communicate to children about unmentioned categories. Psychological Science, 32(2), 189-203. https://doi. org/10.1177/0956797620953132

Nasie, M., Diamond, A. H., \& Bar-Tal, D. (2016). Young children in intractable conflicts: The Israeli case. Personality and Social Psychology Review, 20(4), 365-392. https://doi. org/10.1177/1088868315607800
Nesdale, D. (2017). Children and social groups: A social identity approach. In A. Rutland, D. Nesdale, \& C. S. Brown (Eds.), The Wiley handbook of group processes in children and adolescents (pp. 1-22). John Wiley \& Sons. https://doi.org/10.1002/9781118773123.ch1

Nesdale, D., \& Dalton, D. (2011). Children's social groups and intergroup prejudice: Assessing the influence and inhibition of social group norms. British Journal of Developmental Psychology, 29(Pt 4), 895-909. https://doi. org/10.1111/j.2044-835X.2010.02017.x

Nesdale, D., Griffith, J., Durkin, K., \& Maass, A. (2005). Empathy, group norms and children's ethnic attitudes. Journal of Applied Developmental Psychology, 26(6), 623-637. https:// doi.org/10.1016/j.appdev.2005.08.003

Nesdale, D., \& Lawson, M. J. (2011). Social groups and children's intergroup attitudes: Can school norms moderate the effects of social group norms? Child Development, 82(5), 1594-1606. https://doi.org/10.1111/j.14678624.2011.01637.x

Ng Tseung Wong, C., \& Verkuyten, M. (2015). Multiculturalism Mauritian style: Cultural diversity, belonging and a secular state. The American Behavioral Scientist, 59(6), 679-701. https://doi.org/10.1177/0002764214566498

Oakes, P. J., Haslam, S. A., \& Turner, J. C. (1994). Stereotyping and social reality. Blackwell.

Olson, K. R., \& Dunham, Y. (2010). The development of implicit social cognition. In B. Gawronski \& B. K. Payne (Eds.), Handbook of implicit social cognition: Measurement, theory, and applications (pp. 241-254). The Guilford Press.

Peters, W. (Director) (1970). The eye of the storm [Film]. American Broadcasting Company.

Piaget, J. (1929). The child's conception of the world. Routledge and Kegan Paul.

Powell, L. J., \& Spelke, E. S. (2013). Preverbal infants expect members of social groups to act alike. Proceedings of the National Academy of Sciences of the United States of America, 110(41), E3965-E3972. https://doi. org/10.1073/pnas. 1304326110

Rabbie, J. M., \& Horwitz, M. (1969). Arousal of ingroup-outgroup bias by a chance win or loss. Journal of Personality and Social Psychology, 13(3), 269-277. https://doi.org/10.1037/ h0028284

Reicher, S., Spears, R., \& Haslam, S. A. (2010). The social identity approach in social psychology. In M. Wetherell \& C. T. Mohanty (Eds.), The Sage handbook of identities (pp. 45-62). Sage. https://doi.org/10.4135/9781446200889.n4

Robbins, J. M., \& Krueger, J. I. (2005). Social projection to ingroups and outgroups: A review and meta-analysis. Personality and Social Psychology Review, 9(1), 32-47. https://doi. org/10.1207/s15327957pspr0901_3

Roberts, S. O., Ho, A. K., \& Gelman, S. A. (2021). Should individuals think like their group? A descriptive-to-prescriptive tendency toward group-based beliefs. Child Development, 92(2), e201-e220. https://doi.org/10.1111/ cdev. 13448
Group Identity and Ingroup Bias: The

Social Identity Approach
Human Development 2021;65:311-324 DOI: $10.1159 / 000519089$ 
Rosenberg, M. (1979). Conceiving the self. Basic Books.

Ruble, D. N., Alvarez, J., Bachman, M., Cameron, J., Fuligni, A., Garcia Coll, C., \& Rhee, E. (2004). The development of a sense of "we": The emergence and implications of children's collective identity. In M. Bennett \& F. Sani (Eds.), The development of the social self (pp. 29-76). Psychology Press. https://doi. org/10.4324/9780203391099_chapter_2

Ruble, D. N., Parsons, J. E., \& Rioss, J. (1976). Selfevaluative responses of children in an achievement setting. Child Development, 47(4), 990997. https://doi.org/10.2307/1128435

Rutland, A. (2004). The development and selfregulation of intergroup attitudes in children. In M. Bennett \& F. Sani (Eds.), The development of the social self (pp. 247-265). Psychology Press. https://doi.org/10.4324/ 9780203391099_chapter_9

Rutland, A., Brown, R. J., Cameron, L., Ahmavaara, A., Arnold, K., \& Samson, J. (2007). Development of the positive-negative asymmetry effect: In-group exclusion norm as a mediator of children's evaluations on negative attitudes. European Journal of Social Psychology, 37(1), 171-190. https://doi.org/10.1002/ ejsp. 342

Rutland, A., Hitti, A., Mulvey, K. L., Abrams, D., \& Killen, M. (2015). When does the in-group like the out-group? Bias among children as a function of group norms. Psychological Science, 26(6), 834-842. https://doi.org/10.1177/ 0956797615572758

Sani, F., \& Bennett, M. (2004). Developmental aspects of social identity. In M. Bennett \& F. Sani (Eds.), The development of the social self (pp. 77-100). Psychology Press. https://doi. org/10.4324/9780203391099_chapter_3

Schmidt, M. F. H., \& Rakoczy, H. (2018). Developing an understanding of normativity. In A. Newen, L. de Bruin, \& S. Gallagher (Eds.), Oxford handbook of cognition: Embodied, embedded, enactive and extended. Oxford University Press.

Schmidt, M. F., \& Sommerville, J. A. (2011). Fairness expectations and altruistic sharing in 15-month-old human infants. PLoS One, 6(10), e23223. https://doi.org/10.1371/journal.pone. 0023223

Sierksma, J., Thijs, J., \& Verkuyten, M. (2014). Children's intergroup helping: The role of empathy and peer group norms. Journal of Experimental Child Psychology, 126, 369-383. https://doi.org/10.1016/j.jecp.2014.06.002

Sierksma, J., Thijs, J., \& Verkuyten, M. (2015). Ingroup bias in children's intention to help can be overpowered by inducing empathy. British Journal of Developmental Psychology, 33(1), 45-56. https://doi.org/10.1111/bjdp. 12065

Skitka, L. J., Hanson, B. E., Morgan, G. S., \& Wisneski, D. C. (2021). The psychology of moral conviction. Annual Review of Psychology, 72(1), 347-366. https://doi.org/10.1146/annurev-psych-063020-030612
Spears, R., \& Otten, S. (2012). Discrimination: Revisiting Tajfel's minimal group studies. In J. R Smith \& S. A. Haslam (Eds.), Social psychology: Revisiting the classic studies (pp. 160-177). Sage.

Spielman, D. A. (2000). Young children, minimal groups, and dichotomous categorization. Personality and Social Psychology Bulletin, 26(11), 1433-1441. https://doi.org/10.1177/ 0146167200263010

Srinivasan, M., Kaplan, E., \& Dahl, A. (2019). Reasoning about the scope of religious norms: Evidence from Hindu and Muslim children in India. Child Development, 90(6), e783-e802. https://doi.org/10.1111/cdev.13102

Taijfel, H. (1970). Experiments in intergroup discrimination. Scientific American, 223(5), 96102. https://doi.org/10.1038/scientificamerican1170-96

Tajfel, H., Flament, C., Billig, M., \& Bundy, R. P. (1971). Social categorization and intergroup behavior. European Journal of Social Psychology, 1(2), 149-178. https://doi.org/10.1002/ ejsp. 2420010202

Tajfel, H., \& Turner, J. (1979). An integrative theory of intergroup conflict. In W. G. Austin \& S. Worchel (Eds.), The social psychology of intergroup relations (pp. 33-47). Brooks/Cole.

Thijs, J., \& Verkuyten, M. (2016). Ethnic attitudes and social projection in the classroom. Child Development, 87(5), 1452-1465. https://doi. org/10.1111/cdev.12597

Thijs, J., \& Zee, M. (2019). Further evidence for social projection in the classroom: Predicting perceived ethnic norms. Journal of Applied Developmental Psychology, 62, 239-248. https://doi.org/10.1016/j.appdev.2019.03.006

Turiel, E. (2002). The culture of morality. Cambridge University Press.

Turiel, E., \& Gingo, M. (2017). Development in the moral domain: Coordination and the need to consider other domains of social reasoning. In N. Budwig, E. Turiel, \& P. D. Zelado (Eds.), New perspectives on human development (pp. 209-228). Cambridge University Press. CBO9781316282755.013

Turner, J. C. (1991). Social influence. Open University Press.

Van Ausdale, D., \& Feagan, J. R. (2002). The first $R$ : How children learn race and racism. Rowman and Littlefield.

Vanbeselaere, N. (1987). The effects of dichotomous and crossed social categorizations upon intergroup discrimination. European Journal of Social Psychology, 17(2), 143-156. https:// doi.org/10.1002/ejsp.2420170203

Van Bommel, G., Thijs, J., \& Miklikowska, M. (2021). Parallel empathy and group attitudes in late childhood: The role of perceived peer group attitudes. The Journal of Social Psychology, 161(3), 337-350. https://doi.org/10.1080 /00224545.2020.1840326
Van Veelen, R., Otten, S., Cadinu, M., \& Hansen, N. (2016). An integrative model of social identification: Self-stereotyping and self-anchoring as two cognitive pathways. Personality and Social Psychology Review, 20(1), 3-26. https://doi.org/10.1177/1088868315576642

Verkuyten, M. (2003). Ethnic in-group bias among minority and majority early adolescents: The perception of negative peer behaviour. British Journal of Developmental Psychology, 21(4), 543-565. https://doi. org/10.1348/026151003322535219

Verkuyten, M. (2007). Ethnic in-group favoritism among minority and majority groups: Testing the self-esteem hypothesis among preadolescents. Journal of Applied Social Psychology, 37(3), 486-500. https://doi.org/10.1111/ j.1559-1816.2007.00170.x

Verkuyten, M. (2016). Further conceptualizing ethnic and racial identity research: The social identity approach and its dynamic model. Child Development, 87(6), 1796-1812. https:// doi.org/10.1111/cdev.12555

Verkuyten, M. (2018). The social psychology of ethnic identity (2nd ed.). Routledge. https:// doi.org/10.4324/9781315109527

Verkuyten, M., \& De Wolf, A. (2007). The development of in-group favoritism: Between social reality and group identity. Developmental Psychology, 43(4), 901-911. https://doi. org/10.1037/0012-1649.43.4.901

Verkuyten, M., \& Pouliasi, K. (2002). Biculturalism among older children: Cultural frame switching, attributions, self-identification and attitudes. Journal of Cross-Cultural Psychology, 33(6), 596-608. https://doi.org/ $10.1177 / 0022022102238271$

Verkuyten, M., \& Steenhuis, A. (2005). Preadolescents' understanding and reasoning about asylum seeker peers and friendships. Journal of Applied Developmental Psychology, 26(6), 660-679. https://doi.org/10.1016/j.appdev.2005.08.002

Verkuyten, M., \& Thijs, J. (2013). Multicultural education and inter-ethnic attitudes: An intergroup perspective. European Psychologist, 18(3), 179-190. https://doi.org/10.1027/10169040/a000152

Warneken, F., \& Tomasello, M. (2006). Altruistic helping in human infants and young chimpanzees. Science, 311(5765), 1301-1303. https://doi.org/10.1126/science.1121448

Waxman, S. R. (2010). Names will never hurt me? Naming and the development of racial and gender categories in preschool-aged children. European Journal of Social Psychology, 40(4), 593-610. https://doi.org/10.1002/ejsp.732

Yee, M. D., \& Brown, R. (1992). Self-evaluations and intergroup attitudes in children aged three to nine. Child Development, 63(3), 619629. https://doi.org/10.2307/1131350

Yzerbyt, V. Y. (2018). The dimensional compensation model: Reality and strategic constraints on warmth and competence in intergroup perceptions. In A. E. Abele \& B. Wojciszke (Eds.), The agency-communion framework (pp. 126-141). Routledge. 